ELORE (ISSN 1456-3010), vol. 19 - 2/2012.

Julkaisija: Suomen Kansantietouden Tutkijain Seura ry.

[http://www.elore.fi/arkisto/2_12/knuuttila.pdf]

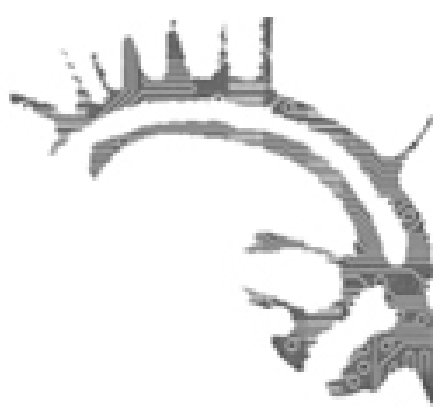

\title{
EMINENTIA-LIITE
}

\section{FOLKLORISTIIKAN TIEDOLLISISTA HIERARKIOISTA KÄSITTEELLISEEN RELATIVISMIIN}

\author{
Seppo Knuuttila
}

Esitelmä Suomen Kansantietouden Tutkijain Seuran VI Kevätkoulun Eminentialuennot-seminaarissa 15.5.2012 Tieteiden talossa Helsingissä.

Yleisestä ei pidä suoraviivaisesti tehdä erityistä koskevia päätelmiä, eikä yksittäisistä perinnemuistiinpanoista pidä ilman vertailuaineistoa johtaa yleistyksiä. Nämä olivat folkloristiikan tärkeimmät, tai ainakin mieleen painuvimmat metodiset ohjeet alan opiskelijalle 1970-luvulla. Yleisen ja erityisen suhteisiin liittyy edelleen monia kiinnostavia kysymyksiä, kuten globaalin käsitteen monitulkintaisuudesta ja mikrohistoriallisen tutkimustavan tieto-opista sekä sen kritiikistä olemme oppineet.

Kaikkia kulttuurintutkimuksen aloja rikastuttaneet tieto-opilliset käänteet 1980luvulla jättivät jälkensä myös folkloristiikkaan, vaikka mitään vallankumousta ei meidän alallamme tapahtunutkaan. Yksi merkittävä seuraus tuon ajan keskusteluista kuitenkin oli, että tutkimuksissa alettiin aiempaa enemmän avata astelujen lähtökohtia, teoreettisia ja metodisia valintoja, problematisoida aineistojen tuottamista ja arvioida tutkimustulosten tulkinnanvaraisuutta.

Lähden seuraavassa liikkeelle folkloristiikan ostensiivisesta eli merkitysten osoittamisen tieto-opista sekä merkityksenantoon liittyvästä konstruktiivisuuden ongelmasta. Laajasti ottaen pohdiskeluni liittyvät kansanomaisen maailmankuvan havainnonmukaisuuden artikulaatioihin ja niiden representaatioihin. Ostensiivisen käsitealassa viittaamisen lisäksi olennaista on tuoda esiin, mitä on tiedettävä ennen kuin joku, esimerkiksi intui- 
tion vastainen havainto nimetään niin, että informaation vastaanottajat tulkitsevat ja/ tai ymmärtävät sen kutakuinkin samoin.

Tarkastelen myös esimerkin luontoisesti folkloristiikassa usein esillä ollutta, joskaan ei tieto-opillisesti kovin merkittävänä pidettyä asiaa, nimittäin yliluonnollisen aistittavuutta. Lähtökohtana on pidetty ja pidetään kaiketi edelleen, että asialliset tieteenharjoittajat eivät usko yliluonnolliseen eivätkä näe ja kuule olemattomia tai ovat ainakin tuomatta näitä seikkoja tutkimukseen. Mutta heillä/meillä ei myöskään ole enää tapana kiistää tai trivialisoida kertojien selittämättömiä elämyksiä, outoja aistimuksia ja kokemuksia yliluonnollisesta. Tämän problematiikan yhtenä mahdollisena avaajana tuon esiin käsitteellisen relativismin näkökulman sellaisena kuin kulttuurintutkimuksen tieto- ja käsiteopin tutkija Inkeri Koskinen on sitä filosofian näkökulmasta tarkastellut.

\section{TOTEAVUUDESTA KOETELTAVUUTEEN}

Outi Lehtipuro kirjoitti Perinteentutkimuksen perusteita-kirjan johdannossa vuonna 1980, että suomalaisessa folkloristiikassa oli alkanut 1960-luvulla uudenlainen metodikeskustelu, jossa tekstitutkimuksen valta-asemasta oltiin siirtymässä antropologisen folkloristiikan suuntaan. Samalla hän kertoo käyneen niin, että "vaatimus tutkimuksen metodien ja käsitteiden entistä selväsanaisemmasta esillepanosta on kuitenkin vähitellen alkanut kotiutua humanistiseenkin ajatteluun" (1980, 8-9). Kyseisessä artikkelikokoelmassa on neljä laajaa artikkelia, joissa selvitellään vertailevan runotutkimuksen menetelmää, haltijaperinteentutkimuksen terminologian konstruointia sekä tarkastellaan perinteen yhteisöllisyyden ja yksilöllisyyden kysymyksiä. Kirja on hyvä dokumentti kolmenkymmenen vuoden takaa muun muassa siitä, mitä alan tieto-opin ja siihen johtavien metodisten käytäntöjen ajateltiin olevan. Läpikäyvänä ajatuksena oli, että perinteentutkimuksen kohde on "jossakin valmiina odottamassa", ja osaavalla aineiston hankinnalla ja tulkinnalla se voidaan selittää ja tehdä ymmärrettäväksi nykyajassa. Tuohon aikaan ei kuulunut ajatus, että tutkija osallistuu aktiivisesti aineistojen konstruointiin ja on osa tutkimusprosessia, mikä nykyään on useimmille folkloristeille itsestään selvä empiirinen lähtökohta.

Folkloristiikan tieto-oppiin liittyvä merkittävä uudelleen arviointi vuosituhannen vaihteen tienoilla on koskenut tutkimustulosten pysyvyyden pohdintaa suhteessa kulttuurin ja yhteiskunnan muutoksiin. Tätä problematiikkaa on pitänyt meidän folkloristeistamme esillä erityisesti Pertti Anttonen, joka kirjassaan Tradition through Modernity (2005) on tarkastellut monipuolisesti sitä, miten (myöhäisen) modernin kontekstuaaliset tekijät ilmenevät folkloristiikan yhteiskunnallisissa kytkennöissä ja siten myös tutkimuksen paradigmojen vaihdoksissa. Anttosen tarkastelun punaisena lankana on kansakunnan ja valtion historiallinen, poliittinen ja kulttuurinen konstruointi/konstruoituminen, mikä on ollut vaihtelevin tavoin sekä tarkoitushakuista että päämäärätietoista.

Kun folkloristiikan oppihistoriaa on jäsennetty viime vuosisadan jälkipuolella Jouko Hautalan yleisesityksen (1954) jälkeen, useimmiten huomiota on kiinnitetty siihen, miten puhtaaksi viljellyn tekstien tutkimuksen rinnalla alettiin pohtia perinteen mer- 
kitystä ihmisille itselleen ja perinteen suhdetta erilaisiin muihin kulttuurin ilmiöihin. Suomessakin luettiin jo 1970-luvun puolivälin paikkeilla uudesta amerikkalaisesta folkloristiikasta; siinä pääpaino oli tekstien sijasta esityksissä ja varsinkin konteksteissa, jotka ymmärrettiin perinteen merkityspotentiaalien kannalta ensiarvoisen tärkeiksi.

Folkloristisen tekstitutkimuksen ja antropologisen folkloristiikan paradigmoja seurasi Sinikka Vakimon mukaan 1900-luvun lopulla "tutkimussuuntien eriytymisen vaihe, jossa sosiaalisella konstruktiolla ja kielellisten merkitysten tulkinnalla on ollut keskeinen sija ja jossa perinnettä taitava tai soveltava ihminen määrittyy oman maailmansa tulkitsijaksi” (2008). Tämä luonnehdinta kuvaa itse asiassa hyvin myös sitä, että tälle vuosituhannelle tultaessa folkloristiikan tieto-oppi on alkanut enenevässä määrit tukeutua konstruktionistiseen tiedon teoriaan, jolloin tavoitteena ei ole kuvata tai osoittaa sitä, miten teksti tulkitsee todellisuutta vaan, miten teksti sanan laajassa merkityksessä puhuttuna, kirjoitettuna tai muuten esitettynä kulttuurisena ilmauksena myös on ja tuottaa sitä - ja sikäli myös meidät kulttuurisina olioina.

Kun tutkimus - alalla kuin alalla - on aktiivisessa tilassa, uusien oppien ja tulkintojen valossa menneiden vuosien, vuosikymmenten ja -satojen katsomuksia arvioidaan jatkuvasti uudelleen. Näin on käynyt esimerkiksi folkloristisen maailmankuvien tutkimuksen piirissä, jossa yhtenä viimeaikaisena trendinä näyttää olleen osoittaa kansaomaisen ajattelun käsitteellinen luonne ja se, että kollektiiviperinteen merkityksenantoprosessit ovat olleet niin aistimuksellisesti kuin emotionaalisesti ja kokemuksellisestikin myös yksilöllisiä. Vaikkapa Senni Timosen sanoin: "[...] lyyriset laulut kantavat, suoremmin kuin monet muut perinteenlajit, viestejä yksityistenkin laulajien ainutkertaisista kokemuksista ja heidän tavoistaan tulkita niitä” $(2004,36)$.

\section{KANSANOMAISEN MAAILMANKUVAN AISTIMELLISUUS}

Pitkän ja vaikuttavan tulkintalinjan mukaan kaikki "selittämätön" on selitetty luonnollisesti, mikä on tieto-opillisesti fundamentalistinen lähtökohta kieltäessään ei-olevan aistittavuuden. Antiikista periytyvän (Palaephatus, Herakleitos, Euhemeros) peripateettisen aksiooman (Aristoteles / Tuomas Akvinolainen) mukaisesti mielessä ei ole mitään, mikä ei ensin ole ollut aisteissa. Fundamentalistiseen ehdottomuusoletukseen kriittisesti suhtautuvan tarkastelutavan asenteena taas on ollut intuitionvastaisten elämys- ja kokemuskertomusten ymmärtäminen, tulkinta ja "silleen jättäminen"; tätä voisi luonnehtia maailmankuvan koherenssiteoriaksi, eli uskomukset ja niiden ilmaukset saavat merkityksensä toisistaan, mikä otaksuma on usein liittoutunut kontekstuaalisten tarkastelujen kanssa. Näin päädytään kiertoteitse relativismin tieto-oppia koskevien kysymysten äärelle (palaan niihin tuonnempana).

Kansanomaisen maailmankuvan keskeisinä kriteereinä on niin 1900-luvun antropologiassa kuin etnologiatieteissäkin pidetty kollektiivisuuden ja perinteellisyyden lisäksi omaan kulttuuriin rajautumista ja konkreettisuutta. Maailmankuvan käsitteellisimmän ulottuvuuden on folkloristiikan ja kansanuskon tutkimuskirjallisuudessa esitetty etupäässä koskevan sitä, mitä on havaittujen ja tiedettyjen rajojen tuolla puolen: millaista 
on olla toinen ihminen tai eläin; mitä on tuonelassa käynti; miten ajattomuus ja äärettömyys ovat kuviteltavissa; voiko yliluonnollisia ilmiöitä aistia; miten voidaan varmistua havainnon ulottumattomissa olevan maailman todellisuudesta tai edes mahdollisuudesta.

Tieto-opillisesti ei-olevan entiteetti on tietenkin paradoksi, jos tarkastelun ajatellaan aktuaalisti kohdistuvan vain sellaiseen, mitä ei yksinkertaisesti ole. Mutta kun jäljitetään ei-olevaa koskevan pohdinnan kulttuurihistoriallisia vaiheita, oletuksia ja päätelmiä, paradoksin ala kaventuu merkittävästi, vaikkakaan se ei kokonaan häviäkään. Paradoksin tuottaminen ja kuvitteleminen on näet ihmisen mielellinen kyky.

Ajatus ympäristöhavaintojen ja mielikuvituksen vuorovaikutuksesta toistuu useissa myyttiteorioissa ja mytologian tulkinnoissa. Anna-Leena Siikala on muun muassa Claude Lévi-Straussiin ja George Lakoffiin viitaten esittänyt, että myyttiset mielikuvat eivät ole suoria havaintoja ympäristöstä, mutta ne viittaavat havaintomaailmasta myyttisen maailman ilmiöihin ja tapahtumiin (1992, 43-44) - ja saavat ihmiset havaitsemaan asioita, joita myytit ja mielikuvitus ruokkivat. Lisäksi sellaisetkin mielikuvat, jotka eivät perustu aistihavaintoihin, voidaan tehdä esimerkiksi taiteiden keinoin näkyviksi. Niinpä Kalevalankin episodit myyttiseen maailmaan viitatessaan esitetään kuultuina ja nähtyinä; ongelmallisuudessaan hyvä esimerkki on Sampo, jonka kuvalliset esitykset ovat epämääräisyydessään vaihtelevia, sillä kukapa todellinen henkilö olisi sen esineenä nähnyt. Idean ja esityksen dialektinen suhde näyttää toimivan ja aiheuttavan myös väärinkäsityksiä kaikilla kielenkäytön tasoilla.

Stephen W. Hawking aloittaa kirjansa Ajan lybyt historia (1989) anekdootilla tiedemiehestä, joka tähtitieteen yleisöluennolla kertoi kuulijoilleen miten Maa kiertää Aurinkoa ja Aurinko puolestaan kiertää suurta, Linnunradaksi kutsuttua tähtijoukkoa.

Luennon päätyttyä takarivin pieni mummeli pyysi puheenvuoron.

- Tuo mitä kerroitte on täyttä soopaa, mummeli sanoi. Maapallohan on litteä levy, jota suunnaton kilpikonna kantaa selässään.

Tiedemies hymyili alentuvasti ja kysyi vuorostaan:

- Entä se kilpikonna? Mistä se saa tukea?

Mummelilla oli heti vastaus valmiina:

- Älkää olko nenäkäs, nuori mies. Kilpikonnahan saa tukea alla olevasta toisesta kilpikonnasta ja se taas seuraavasta kilpikonnasta. Niin se on.

Hawking palaa kirjansa yhteenvedossa tähän esimerkkiin ja toteaa, että loputon torni toistensa selässä seisovia kilpikonnia on yhdenlainen maailmankuva, ja niin on myös teoria supersäikeistä. Kumpikin kuvaa maailmankaikkeutta, joskin säieteoria on paljon matemaattisempi ja siksi täsmällisempi. Hawkingin näkökulmasta koko kilpikonnajuttu on pelkkää muinaispötyä. (1989, 1-2, 169-170.)

Kun kosmologi Kari Enqvist kirjoittaa, että "alkuräjähdysteoriaa kannattelee kolme pilaria", useimmat lukijat tajuavat pilarit ja kannattelun vertauskuviksi, joita kirjoittaja käyttää tehdäkseen asian ymmärrettäväksi maallikkolukijalle. Pilareista, jatkaa Enqvist, "kosminen mikroaaltotausta on jykevin. Toinen pilari on galaksien etäisyyksiä seuraileva ja avaruuden laajenemisesta kertova spektriviivojen systemaattinen punertuminen; kuten jo totesimme, tätä pilaria muurataan parhaillaan kovaa vauhtia paksummaksi. Nämä 
molemmat tukijalat voidaan rakentaa suoraan havaitun perustalle. Sen sijaan alkuräjähdysteorian kolmas kannatinpylväs muodostuu päättelyketjusta, joka vie meidät aina yhden sekunnin päähän alkuhetkestä.” Enqvist laajentaa näkökulmaansa siteeraamalla Eeva-Liisa Mannerin runoa "Kromaattiset tasot", jossa "Aine omaksuu energian kulkuja, ne ovat sen sisältöjä." (Enqvist 2003, 110.)

Teorian pilarien muuraaminen ja tukijalkojen rakentaminen ovat tieteen ja tutkimuksen toiminnallisia vertauskuvia. Mutta ongelmallista onkin se, miksi Hawkingin mainitseman takarivin vanhan naisen, mummelin kuvitellaan ajatellun kirjaimellisesti? Eikö ole mahdollista, jopa todennäköistä, että hän(kin) ymmärsi maailman myyttisen rakenteen vertauskuvallisesti. Myytti maailman tukeutumisesta pilarien varaan ja supersäietoria kuuluvat tietenkin erilaisiin tiedonkategorioihin. Tästä myös Enqvist osoittaa olevansa tietoinen, kun hän - toisessa yhteydessä - kirjoittaa fiktiivisen sinä-henkilönsä joutuvan maailmaan, jossa kaikki on kuin täällä, paitsi että siellä taivaan sanotaan olevan keltainen.

Vähitellen ymmärrät:

\begin{abstract}
Sanoessaan 'Taivas on keltainen' X:n kuvernementin N:n kaupungin asukkaat eivät viittaa havaintoon mutta eivät myöskään pelkkään tunteeseen. Pikemmin tämä lause [...] kannattelee suurta kuormaa muita ääneen lausumattomia uskomuksia. Avaimen lailla se sopii tietynlaiseen lukkoon. Se avaa oven, jonka takaa löytyy kokonainen elämänmuoto, joka muodostuu osin artikuloimattomien säännösten ja tuntemusten vyyhdistä.

(Enqvist 2004, 140).
\end{abstract}

Tästäkin voisi jatkaa Manneria lainaamalla: "[...] sana on heille yhä loitsu, he uskovat niihin, ja toinenkin uskoo, ainakin sen illan: Totta, tällä kaupungillahan on helvetin värit” (Manner 1968, 67).

Antropologi Clifford Geertz on kuullut Hawkingin lainaamasta kertomuksesta sellaisen version, jossa maailman esitetään rakentuneen tasanteelle, jota kannattelee kilpikonnatornin päällä seisova elefantti. Geertz ei ryhdy pohtimaan kertomukseen sisältyvän myytin kirjaimellista mahdottomuutta, vaan tarkastelee kertomusta tiedon arkeologian vertauskuvana ja muistutuksena kulttuurianalyysin rajoituksista. Hänen mielestään sellaisessa tieteessä on jotakin perin outoa ja kiehtovaa, jonka antoisimmat ja tärkeimmät tulokset ovat samanaikaisesti kaikkein epämääräisimpiä, syvimmällä olevia kilpikonnia (Geertz 1973, 28-30). Näin Geertz ja Enqvist tulevat tavallaan samalle kynnykselle, joskin edellinen astuu sen yli, antropologi kun on. Mutta Enqvist kosmologina jättää asian sikseen, koska hänen kannaltaan kaikki merkityksellinen ja kiinnostava on jo tapahtunut kauan, kauan sitten. Merkityksellinen ero on siinäkin, että Geertz ei vertaa kilpikonnatorniteoriaa mihinkään toiseen, mahdollisesti kilpailevaan maailmanselitykseen vaan katsoo, että se on itsessään myyttien askarruttavuuden ilmentymä. 


\section{METODINEN KÄSITTEELLINEN RELATIVISMI}

Tiedollisen relativismin oppi sai muun muassa antropologiassa täyslaidallisen kritiikkiä toisen maailmansodan jälkeisinä vuosikymmeninä - osa siitä kohdistui myös Geertzin tulkitsevaan tutkimusotteeseen. "Jos kaikki on totta ja hyväksyttävää, niin toden ja hyväksyttävän kriteerit katoavat", pääteltiin. Sittemmin relativismia koskevissa keskusteluissa on edetty joko-tai-asetelmista kontekstuaaliseen suuntaan, jolloin on korostettu eroa muun muassa moraalisen, ajallisen, ontologisen, tiedollisen ja metodisen relativismin välillä.

Metodisen käsitteellisen relativismin soveltuvuutta etnografian käytäntöihin on tarkastellut Inkeri Koskinen artikkelissaan "Seemingly Similar Beliefs: A Case Study on Relativistic Reserach Practices" (2011). Koskisen teesi lyhyesti on, ettei etnografisissa, kenttätöihin perustuvissa tutkimuksissa ole nykyään havaittavissa laajasti kritisoitua tiedollista relativismia. Tämä on tärkeä havainto sen vuoksi, että se avaa pohdintoja erilaisten ja -asteisten relativismien arvioinneille.

Koskisen artikkelin lähtökohtana on keskustelu, jonka tässä tapauksessa amerikkalainen tieteen/tiedonfilosofi Paul Boghossian on herättänyt vuonna 2006 ilmestyneellä kirjallaan Fear of Knowledge. Against Relativism and Constructivism. Koskinen on kiinnittänyt huomiota erityisesti siihen, miten Boghossian on eräisiin arkeologien tiedekäsityksiin viitaten ryhtynyt purkamaan otaksumaa, jonka mukaan tiede olisi vain yksi uskomusjärjestelmä muiden joukossa. Tätä Boghossian luonnehtii postmodernin relativismin käsitteellä, joka on hänen mukaansa tiedollisen relativismin pohjanoteeraus.

Koskinen on tiivistänyt tämän relativismikeskustelun ja siinä esiin tulleet väitteet, joita vastaan hän siis argumentoi, seuraavasti: "[...] postmoderni relativismi eli totuusnihilismi on vaarallista, koska se rapauttaa tieteellisen argumentaation tasoa. Postmoderni relativisti ei tee eroa hyvän ja huonon argumentin tai perustellun ja perusteettoman väitteen välillä, joten hän hyväksyy kaikki poliittisesti mieluisat tutkimukset riippumatta niiden tieteellisistä ansioista" (Boghossian 2010, 66). Koska me uskoakseni ajattelemme, ettei tällainen voi (enää) koskea meitä folkloristeja, on hyvä pohtia tässä hieman sitäkin, että jos ei, niin millä perusteella ei. Inkeri Koskinen esittää itse yhden tulkinnan erittelemällä Anna-Leena Siikalan Udmurtiaan paikantuvia kenttätutkimuksia ja valaisee niiden avulla toisenlaisia relatiivisia lähestymistapoja.

Erilaisten ja -aikaisten maailmankuvien, teorioiden ja tulkintojen yhtäläisyys ei ole tietääkseni minkään vakavasti otettavan etnografisen tutkimussuuntauksen johtoajatus. Tutkijat ovat koulutuksensa sekä tiedeyhteisöön ja sen pelisääntöihin sitoutumisen vuoksi sisäistäneet tiedeperustaisen maailmankuvan, mikä implikoi sen, että toisenlaiset maailmankuvat voivat olla ja usein myös ovat heidän tutkimuskohteitaan. Kiinnostava kysymys, jonka Koskinenkin tavallaan jättää avoimeksi, kuuluu, voiko etnografi/folkloristi esimerkiksi ohittaa kokonaan kysymyksen erilaisten maailmankuvien arvottamisesta, tai ovatko esimerkiksi uskontotieteilijälle kaikki uskonnot periaatteessa samanarvoisia. Jos vastaus olisi myöntävä, oltaisiin syystäkin tiedollisesta relativismista syytettyjen penkillä.

Tiedolliseen relativismiin yhdistetty oppi erilaisten maailmankuvien ja -selitysten samanarvoisuudesta on ollut pitkään kritiikin kohteena; tällaisella naiivilla relativismilla ei kuitenkaan ole nykyään käytännöllisesti katsoen lainkaan puolestapuhujia. Koskinen on verrannut tilannetta Ian Hackingin havaintoon (2009), jonka mukaan radikaalin 
ja/tai universaalin sosiaalisen (tai kulttuurisen) konstruktionismin vakavasti otettavia edustajia tiedemaailmasta tuskin löytää.

Inkeri Koskinen on tarkastellut Anna-Leena Siikalan kenttätutkimuksia siitä näkökulmasta, miten niissä näkyy tai on näkymättä mahdollinen tiedollinen relativismi ja maailmankuvien samanarvoisuuden argumentaatio. Sen lisäksi, että Koskinen on ottanut tarkasteluun yhdeksän Siikalan julkaisemaa tekstiä (artikkelia), hän on keskustellut Siikalan kanssa relativismin asemasta etnografisessa tutkimuksessa sekä haastatellut tätä kenttätöistä ja -kokemuksista Udmurtiassa. Merkittäviksi Siikalan kenttätyöt ovat osoittautuneet Koskisen aiheen kannalta eritoten siksi, että Siikala on ottanut tarkasteluihinsa mukaan paitsi perinteentaitajia ja riittispesialisteja, myös paikallisia intellektuelleja, jotka ikään kuin välittävät suullisen ja kirjallisen tradition läsnäoloa kansallisen identiteetin konstruktioprosessissa. Siikala painottaa Koskisen mukaan teksteissään erityisesti sitä, että hänen kuvauksensa ja tulkintansa koskevat paikallisia kulttuuri-ilmiöitä, jotka sellaisinaan eivät ole parempia tai huonompia, pätevämpiä tai kelvottomampia kuin esimerkiksi vastaavan tapaiset ilmiöt toisten kulttuurien paikallisissa konteksteissa. Itse asiassa tällaista kysymystä ei ole mielekästä edes esittää, ellei siihen sitten liitetä jonkinlaisia sovellettuja tavoitteita, taloudellisia, ideologisia tai muita pragmaattisia pyrkimyksiä.

Koskisen mielestä Siikalan ja muidenkin samantapaisten esimerkkitapausten perusteella voi todeta, että kansanomaisten ja tieteellisten maailmankuvien samanarvoisuuden oletus ei tule niissä esiin. Sen sijaan Koskinen löysi esimerkkiaineksistaan muun tyyppisiä relativismin tulkintoja. Hänen mukaansa Siikala on soveltanut kenttätutkimuksissaan käsitteellistä relativismia, mikä tarkoittaa sitä, että eri ryhmien tulkintoja vaikkapa uskontoperinteistä ja niiden elvyttämisestä ei vertailla keskenään millään pätevyys- tai arvoasteikolla. Akateemiset ja tutkimukselliset tulkinnat ovat yksinkertaisesti ja selkeästi eri konteksteista kuin ne maailmankuvalliset representaatiot, jotka arkistoituina tai omien kenttätöiden tuloksina ovat olleet tutkijoiden mielenkiinnon kohteina.

Folkloristiikan tieto-opissa on aiempien sukupolvien positivistisista lähtökohdista ja kulttuurihierarkioista edetty viime vuosisadan jälkipuolella, eritoten 1960- ja 1970-luvuilla, sellaisiin relativistisiin suuntauksiin, joissa luonnonkansojen elämänviisautta ja luonnonmukaista elämäntapaa on ylistetty kritiikittömästi. Tällaiset, useammin kuitenkin populaarit kuin tieteelliset esitykset ovat osaltaan antaneet aihetta tiedollisen relativismin kritiikille. Mutta folkloristiikan ja antropologian kenttätöissä ja -tutkimuksissa on parin kolmen viime vuosikymmenen kuluessa siirrytty laajasti Inkeri Koskisen esittelemän metodisen käsitteellisen relativismin suuntaan. Siinä korostuu erilaisten maailmankuvallisten selitysten ja tulkintojen yhteismitattomuus, minkä voi tulkita muun muassa niin, että Hawkingin supersäieteorian ja takarivin naisen kilpikonnatorniteorian rinnastaminen on niin ilmeinen kategoriavirhe, että tuloksena on lähinnä yhteensopimattomuuden komiikkaa, joka muuten näyttääkin huvittavan kosmologeja.

Inkeri Koskinen on todennut, että tutkittavien uskomukset ja argumentit eivät ole tutkijalle sellaisia tiedollisia haasteita, jotka pitäisi hyväksyä tai kumota. Esimerkiksi henkilölle, joka on vastikään nähnyt haltian, tutkijan ei tarvitse eikä ole syytäkään selittää, että kyse on hallusinaatiosta tai jostain muuta luonnolliseksi selitettävästä ilmiöstä. Sen sijaan toisten tutkijoiden samasta ilmiöstä esittämät väitteet ja argumentointi voivat olla haasteita, joihin on syytä vastata. 


\section{AistihaVainnot, mielikuvat Ja RePRESENTAatiot VÄLITTYVINÄ MERKITYKSINÄ}

Olen edellä viitannut jonkun kerran maailmankuvan käsitteeseen, josta takavuosina käytiin melko perusteellinen termikeskustelu. Vaikka tulos jäi avoimeksi, jonkinlainen yksimielisyys näytti syntyvän siitä, että maailmankuva on se tiedollisten käsitysten ja kokemusten kokonaisuus, joka ihmisen on kulttuurinsa jäsenenä hallittava. Määritelmälliset painotukset vaihtelivat sen mukaan, annettiinko maailmankuvalle realistinen, nominalistinen tai konseptualistinen metodinen tulkinta.

Maailman kuva esitettiin pitkään havainnon mukaisena näkymänä ihmisen ympäristöstä, mitä korosti sanojen erillisyys. Kysymyksessä oli havaintoihin perustuva, mielellinen jäsennys ympäristöstä, joka sitten esitettiin myytteinä, satuina, tarinoina, lauluina, liikkeinä, mutta myös visuaalisina kuvina kuten kalliomaalauksina ja -piirroksina. Niissä viimeaikaisissa kalliokuvien tutkimuksissa, joissa on pyritty artikuloimaan visuaalinen esitys myyttisiin representaatioihin, lähtökohtana on usein ollut oletus havainnon mukaisesta maailmasta. Tosin kalliokuvien myyttisiä aihelmia tutkinut arkeologi Antti Lahelma on esittänyt (2008), että kalliokuvista löytyneet geometriset (sik-sak-)kuviot saattavat myös olla psykoaktiivisten aineiden aiheuttamia "sisäisiä kuvia".

Folkloristit ovat käyttäneet mielikuvaa suhteellisen väljänä terminä, joka viittaa yhtäältä havainnon mukaiseen maailmaan, jonka kanssa voidaan kommunikoida eri tavoin. Toisaalta mielikuvalla voidaan viitata melkein mihin tahansa aistimelliseen, intuition vastaiseen elämykseen tai kokemukseen. Anna-Leena Siikalan Suomalainen šamanismi -kirjan alaotsikko on Mielikuvien historiaa (1992). Hänen tulkitseminaan mielikuvat välittyvät sanallisesti, joskin ne edustavat erilaisia ympäristön hahmotus- ja jäsennystapoja.

Lauri Honko nosti mentaalisen tekstin rinnalle mentaalisen kuvan, ja kirjoitti sanan voiman ohella kuvan voimasta. Mentaalinen kuva oli yhtä kuin mielikuva, joka sanallistui myyttisissä teksteissä. (Ks. Honko 1998, 92-99.) Hongon idea kuvan voimasta jäi kuitenkin empiirisesti ohueksi, lähinnä ideatasolle. Se ehkä syntyi koherenssiteorian ohjaamana niin, että mielikuvat saivat vaikutteita kielikuvista ja päinvastoin. Frog on väitöskirjassaan (2010) ja monissa artikkeleissaankin pohtinut mielikuvan /mentaalisen kuvan visuaalista luonnetta ja yhdistänyt sen havainnon mukaisiin ympäristöelementteihin, joille runoteksteissä on annettu symbolisia ja symbolisesti vaikuttavia merkityksiä. Hänen mukaansa myyttisen maiseman visuaaliset aspektit tulevat ymmärrettäviksi ja saavat merkityksensä yhteydestään verbaalisiin esityksiin ja niiden semioottisiin merkityskonstruktioihin. Frogin tekstien ansio on - tämän esityksen kannalta - erityisesti siinä, että hän ei jätä sikseen mentaalisen kuvan / mielikuvan käsitettä, vaan kytkee sen sekä havaittuun maailmaan että sen tulkintoihin niin runoissa kuin tutkimusteksteissä, jolloin tarkasteltavan ilmiön koherenssi ja argumentaatio vahvistuvat.

Kaarina Koski on väitöskirjassaan (2011) kytkenyt mielikuvat kirkonväkeen niin, että kuvaukset vainajia noutavasta tai kimppuun käyvästä kirkonväestä ovat tavalla tai toisella silminnäkijöiden kertomuksia. Samoin Kaarina Kosken ja Pasi Engesin artikkelissa "Mi en ossaas sano mitem mie näin. Erikoisten aistihavaintojen tulkinta uskomusperinteen pohjalta" (2010) tulee esiin se, miten aistihavainnolle haetaan selitystä omasta, yhteisön ja 
perinteen piiristä. Itse asiassa koko se Eloren ansiokas numero (2010/1), jossa käsitellään aistitiedon ulottuvuuksia, on uskollinen metodiselle käsitteelliselle relativismille. Yksi Kosken ja Engesin artikkelin tulos on, että intuition vastainen aistimus tulkitaan tavallista helpommin yliluonnolliseksi, jos muut aistit eivät tue havaintoa. Kiinnostavaa kyllä tällaista yhden aistin havaintoa ja sen tulkintaa on viljelty taajaan myös kansanhuumorissa: esimerkiksi koominen vaikutelma saattaa syntyä, jos nähty ja kuultu ovat ristiriidassa.

Pasi Enges on tuoreessa väitöskirjassaan (2012) edennyt niin ikään käsitteellisen relativismin suuntaan, vaikka ei tätä käsitettä käytäkään. Hän sanoo valinneensa tutkimuksen pääotsikoksi haastattelulainauksen "Minä melkein uskon" osoittaakseen, "että kansanuskossa ei ole kysymys yksinkertaisesta joko-tai-suhtautumisesta, vaan monisyisestä ja monimerkityksisestä uskomusten, asenteiden ja kertomusten verkostosta” (272). Geertziä mukaillen myös uskomusperinne on siis ihmisten välissä ihmeteltynä, neuvoteltuna, epäiltynä ja uskottuna. Jani Närhi on puolestaan kiinnostavassa kirjassaan Paratiisien synty. Ihmismieli, evoluutio ja taivaalliset puutarhat (2009) korostanut sitä, että kognitiivisesti optimaaliset yliluonnolliset oliot ovat "rajoitetusti intuitionvastaisia siten, että jokin niiden ominaisuuksissa loukkaa intuitiivisia odotuksiamme olion luonteesta", ja että" yliluonnollisen ajattelemisessa yhdistyy useiden kategorioiden informaatiota" (119).

Kun ihminen näkee ympäristönsä pysyvyyden ja muuttumisen alituisessa uudelleen hahmottuvassa liikkeessä, hänen havaintonsa sekä tuottavat että ruokkivat ympäristöön liittyviä merkityksiä ja mielikuvia. Kysymys on tällöin pikemmin ihmiselle "lajityypillisestä" kyvystä kuin kulttuurisesti syntyneestä, kukoistaneesta ja katoavasta ilmiöstä. Mutta toistemme havaintoja voimme tarkastella vain sen välityksellä, miten joku niitä on kuvannut, kertonut, maalannut, veistänyt, laulanut, filmannut.

Paul Ricoeur on käsitellyt näitä kysymyksiä laajassa tuotannossaan, jonka yksi läpikäyvä teema on ollut tulkinnan ongelma ja eritoten se, miten kommunikaatio eri lajien ja yksilöiden välillä mahdollista. Hänen mukaansa kokemus ei voi siirtyä yksilöltä toiselle mutta sen merkitys voi (2000):

[...] yhden ihmisen kokemaa ei voida siirtää kokonaisena tiettynä kokemuksena jollekin toiselle. Minun kokemuksestani ei voi suoraan tulla sinun kokemuksesi. Yhteen tajunnanvirtaan kuuluvaa tapahtumaa ei voida sellaisenaan siirtää toiseen tajunnanvirtaan. Silti, kaikesta huolimatta, jotain kulkeutuu minulta sinulle. Jotain siirretään yhdestä elämänpiiristä toiseen. Tämä jokin ei ole kokemus koettuna vaan sen merkitys. Tässä on se ihme. Kokemus koettuna, elettynä, pysyy yksityisenä, mutta sen mieli, sen merkitys, tulee julkiseksi. (43-44.)

Ricoeur siis tähdentää tulkitsevan tutkimuksen fokusoinnin tärkeyttä niin, että kysymys ja analyysi kohdistuvat siihen, mistä jotakin merkityksellistä on perusteltua kysyä ja mihin voidaan perustellusti vastata. Tämä kaksinkertainen argumentaatiovaatimus on sopusoinnussa käsitteellisen relativismin tieto-opin kanssa ja sisältää tavallaan myös pätevän vastauksen ainekset relativismien ja konstruktionismien kriitikoille. 
Seppo Knuuttila: Folkloristiikan tiedollisista hierarkioista käsitteelliseen relativismiin

\section{KirJallisuUs}

ANTTONEN, PERTTI 2005: Tradition through Modernity. Postmodernism and the Nation-State in Folklore Scholarship. Helsinki: SKS.

BOGHOSSIAN, PAUL ARTIN 2006: Fear of Knowledge. Against Relativism and Constructivism. Oxford: Clarendon.

ENGES, PASI 2012: "Minä melkein uskon". Yliluonnollinen ja sen kohtaaminen tenonsaamelaisessa uskomusperinteessä. Turku: Turun yliopisto.

ENQVIST, KARI 2003: Kosmoksen hahmo. Helsinki: WSOY.

ENQVIST, KARI 2004: Vien rucolan takaisin. Helsinki.: WSOY.

FROG 2010: Baldr and Lemminkäinen. Approaching the Evolution of Mythological Narrative through the Activating Power of Expression. A Case Study in Germanic and Finno-Karelian Cultural Contact and Exchange. [online] <http://discovery. ucl.ac.uk/19428/> [10.5.2012.]

GEERTZ, CLIFFORD 1973: The Interpretation of Cultures. Selected Essays. New York: Basic Books.

HACKING, IAN 2009: Mitä sosiaalinen konstruktionismi on? Tampere: Vastapaino. HAUTALA, JOUKO 1954: Suomalainen kansanrunoudentutkimus. Helsinki: SKS.

HAWKING, STEPHEN 1989: Ajan lyhyt historia. Alkuräjähdyksestä mustiin aukkoihin. Helsinki: WSOY.

HONKO, LAURI 1998: Textualising the Siri Epic. Helsinki: Suomalainen Tiedeakatemia.

KOSKI, KAARINA 2011: Kuoleman voimat. Kirkonväki suomalaisessa uskomusperinteessä. Helsinki: SKS.

KOSKI, KAARINA \& ENGES, PASI 2010: "Mi en ossaas sano mitem mie näin". Erikoisten aistihavaintojen tulkinta uskomusperinteen pohjalta. - Elore 17(1). [online] <http://www.elore.fi/arkisto/1_10/art_koski_enges_1_10.pdf> [22.11.2012.]

KOSKINEN, INKERI 2010: Intiaanikreationistit ja tiedollisen relativismin kauhistus. - Niinennän 1.

KOSKINEN, INKERI 2011: Seemingly Similar Beliefs: A Case Study on Relativistic Reserach Practices. - Philosophy of the Social Sciences 41(1).

LAHELMA, ANTTI 2008: A Touch of Red: Archelogical and Ethnographic Approaches to Interpreting Finnish Rock Paintings. Helsinki: Finnish Antiquarian society.

LEHTIPURO, OUTI 1982: Perinteentutkimus tienhaarassa. - Lehtipuro, Outi (toim.), Perinteentutkimuksen perusteita. Helsinki: WSOY.

MANNER, EEVA-LIISA 1968: Fahrenheit 121: runoja. Helsinki: Tammi.

NÄRHI, JUHANI 2009: Paratiisien synty. Ihmismieli, evoluutio ja taivaalliset puutarhat. Helsinki: Art House.

RICOEUR, PAUL 2000: Tulkinnan teoria. Diskurssi ja merkityksen lisä. Helsinki: Tutkijaliitto.

SIIKALA, ANNA-LEENA 1992: Suomalainen šamanismi. Mielikuvien historiaa. Helsinki: SKS. 
Seppo Knuuttila: Folkloristiikan tiedollisista hierarkioista käsitteelliseen relativismiin

TIMONEN, SENNI 2004: Minä, tila tunne. Näkökulmia kalevalamittaiseen lyriikkaan. Helsinki: SKS.

VAKIMO, SINIKKA 2008: Folkoristiikan ikäparadigmoista - kokeilu tieteenalan ihmiskuvan toisin katsomiseksi. - Elore 15(1). [online] <http://www.elore.fi/ arkisto/1_08/vak1_08.pdf> [22.11.2012.]

Seppo Knuuttila on Itä-Suomen yliopiston perinteentutkimuksen professori (emeritus). 